\title{
Compromiso ético en enfermería
}

\section{Ethical commitment in nursing}

E término latín compromissum se utiliza para describir una obligación que se ha contraído; en ocasiones es una promesa o una declaración de principios. Por otra parte, la ética, del latín ethicus, es la rama de la Filosofía que se ocupa del estudio racional de la moral, la virtud, el deber, la felicidad y el buen vivir. Son diversas las profesiones que se comprometen éticamente con las personas a las que cuidan, ejerciendo su disciplina muy de cerca. El profesional de enfermería está autorizado para ofrecer una amplia gama de cuidados y cada uno de ellos implica un compromiso ético.

El compromiso ético es efectivo para quienes lo ejercen en todas sus dimensiones orientado hacia una auténtica realización como personas; busca el perfeccionamiento de cada uno y el mejoramiento de la comunidad humana; es la aplicación en el mundo del verdadero sentido del trabajo. Siete son los valores que guían el comportamiento y compromiso ético: equidad, honestidad, diálogo, solidaridad, respeto, pertenencia y responsabilidad. Por consiguiente, el Compromiso Ético en Enfermería (CEE) es un contrato permanente consigo mismo hacia el perfeccionamiento personal e institucional.

También es un convenio voluntario, individual y manifiesto de quien acepta guiar su conducta por valores éticos que fortalecen la condición humana; en lo personal, invita a que cada quien tome la decisión de reconocer de manera libre a partir del entendimiento y la voluntad, lo que supone una participación activa. El CEE alienta el ejercicio de la autonomía de los miembros de la institución para asumir obligaciones morales en la búsqueda del bien común.

Las características del compromiso ético consisten en: 1. Consciente; por lo tanto es reflexivo, crítico y realista, 2. Personal y libre: es decir, toma cada una de sus propias decisiones sin que represente simple aceptación de lo que otros piensan, dicen o hacen y 3 . Comunitario: aquí el hombre tiene en cuenta que no existe solo, que convive con otros; por lo tanto, supone y reclama acciones solidarias.
Por consiguiente, el compromiso ético es una exigencia con uno mismo; implica esforzarse siempre por ser una mejor persona y tener la decisión interna y libre de asumir actitudes que contribuyan a la realización personal y comunitaria del ser humano; significa el propósito de generar lo que podemos llamar el entorno ético y la decisión firme de superar aquellas situaciones que, en lo personal o comunitario, se oponen a la realización plena del hombre en todas sus dimensiones. La gestión del entorno ético representa todas las acciones encaminadas a lograr un adecuado ambiente laboral generado por los comportamientos de las personas que conforman los grupos de interés de la organización. En el caso de nuestro Instituto, por los jefes de las diferentes áreas, los estudiantes y los administrativos, todos en conjunto, esforzados por lograr una cultura basada en valores éticos, una práctica que afiance las interrelaciones y, por tanto, el quehacer laboral. Es por esto que la gestión del entorno ético del Instituto está fundamentada en la aplicación de los valores del compromiso ético y en la puesta en marcha de un sistema para la seguridad del paciente. Éste permite fortalecer una organización, como la del Instituto Nacional de Neurología y Neurocirugía.

Tal fortalecimiento parte de una Comprensión del Compromiso Ético Institucional (CCEI) y del apoyo de sus directivos, traducido en la aplicación de la gestión ética para ser aplicado en cuatro aspectos fundamentales: comunicación, compromiso, inducción y formación; todo esto orientado a cumplir con los ejes de la Institución (investigación, gestión y educación). Debemos considerar siempre el entorno ético; éste rinde cuenta de las fortalezas y debilidades con el fin de afianzar la ética institucional.

Las personas que conforman el equipo de trabajo de enfermería asumen que la calidad, el servicio y la cultura de la excelencia en la gestión son un compromiso ético insoslayable; representan una actitud de mejora continua de los servicios prestados según las normas y reglas comunes de reconocimiento nacional e internacional. Se obliga a la 
evaluación y certificación externa con criterios reconocidos a fin de mejorar continuamente los resultados y la confianza del entorno, la comunidad académica y la sociedad en general. Así mismo, se observan los aspectos contemplados en el código de ética.

El Código de Ética de Enfermería es un documento que establece en forma clara los principios morales, deberes y obligaciones que guían su buen desempeño profesional en el Instituto Nacional de Neurología y Neurocirugía. Éste exige excelencia en los estándares de la práctica y mantiene una estrecha relación con la Ley de Ejercicio Profesional que determina las normas mínimas aceptadas. El Código de Ética en Enfermería presenta un lenguaje claro, cuenta con marco conceptual y una declaración de principios que sirven de base para el desarrollo de los deberes como profesionista, así como los deberes hacia la Institución y la sociedad.

Ma. Guadalupe Nava Galán 